\title{
Phytotoxin produced by the netted scab pathogen, Streptomyces turgidiscabies strain 65, isolated in Sweden
}

\author{
Masahiro Natsume ${ }^{1} \mathbb{D} \cdot$ Asaho Nagagata $^{2} \cdot$ Marja Aittamaa $^{3} \cdot$ Naoko Okaniwa $^{2} \cdot$ Panu Somervuo ${ }^{3}$. \\ Hans-Peter Fiedler ${ }^{4}$. Jan F. Kreuze ${ }^{5,6} \cdot$ Veli-Matti Rokka $^{7} \cdot$ Hans Bång $^{8} \cdot$ Hiroshi Kawaide $^{1} \cdot$ Jari P. T. Valkonen ${ }^{3,5}$
}

Received: 25 June 2017 / Accepted: 12 November 2017 / Published online: 20 January 2018

(c) The Author(s) 2018. This article is an open access publication

\begin{abstract}
Streptomyces spp. are a highly diverse group of bacteria most of which are soil-inhabiting saprophytes. A few are plant pathogens that produce a family of phytotoxins called thaxtomins and cause significant economic losses, e.g., by reducing the marketability of potato tubers (Solanum tuberosum). In northern Europe, S. scabies, S. turgidiscabies and S. europaeiscabiei are the most common plant pathogenic species. In this study, a Streptomyces strain isolated from a netted scab lesion on a tuber of potato cv. Bintje in northern Sweden was identified as S. turgidiscabies but was found to differ in the genomic region carrying genes required for thaxtomin biosynthesis. Our results showed that the strain did not produce thaxtomin but rather phytotoxin fridamycin E, which is an anthraquinone novel to plant pathogenic Streptomyces spp. Fridamycin E was shown to reduce or inhibit sprouting of potato microtubers in vitro. While fridamycin $\mathrm{E}$ is known to have antibiotic activity against Gram-positive bacteria, the inhibitory activity of fridamycin E on plant growth is a novel finding.
\end{abstract}

Keywords Netted scab $\cdot$ Potato $\cdot$ Streptomyces turgidiscabies $\cdot$ Streptomyces reticuliscabiei $\cdot$ Fridamycin E $\cdot$ Phytotoxin

Electronic supplementary material The online version of this article (https://doi.org/10.1007/s10327-018-0765-8) contains supplementary material, which is available to authorized users.

Masahiro Natsume

natsume@cc.tuat.ac.jp

$\triangle$ Jari P. T. Valkonen

jari.valkonen@helsinki.fi

1 Division of Bioregulation and Biointeraction, Institute of Agriculture, Tokyo University of Agriculture and Technology, Saiwai-cho, Fuchu, Tokyo 183-8509, Japan

2 Graduate School of Agriculture, Tokyo University of Agriculture and Technology, Saiwai-cho, Fuchu, Tokyo 183-8509, Japan

3 Department of Agricultural Sciences, University of Helsinki, Helsinki, Finland

4 Department of Microbiology/Biotechnology, University of Tübingen, Tübingen, Germany

5 Department of Plant Biology and Forest Genetics, Swedish University of Agricultural Sciences (SLU), Uppsala, Sweden

6 International Potato Center (CIP), Lima, Peru

7 AgriFood Research Centre Finland, Jokioinen, Finland

8 Svenskt Potatisutsäde AB, Umeå, Sweden

\section{Introduction}

Bacteria in the genus Streptomyces are Gram-positive and have been classified into 767 species and subspecies (DSMZ 2017). Most species are soil-inhabiting saprophytes, and only a few are plant pathogenic. The streptomycetes that infect potato (Solanum tubersum L.) cause economic losses through reduction of the marketable yield. Diseased potato tubers are characterized by diverse lesions with superficial, raised, erumpent or pitted shapes, that are collectively called common scab to distinguish them from powdery scab, which is caused by the protist Spongospora subterranea (Loria et al. 1997; Loria 2001; Wanner and Kirk 2015). Loria et al. (1997) proposed classifying the lesions into two types: one typified by raised or pitted lesions (so-called "common scab") and the other characterized by superficial lesions.

The first Streptomyces species described as the causal agent of common scab was $S$. scabies (syn. scabiei), which has a worldwide distribution in potato production areas (Lambert and Loria 1989). Another, more recently described and widely distributed species, $S$. turgidiscabies, causes all the aforementioned symptoms on potato tubers (Aittamaa et al. 2010; Hiltunen et al. 2005; Kreuze et al. 1999; Miyajima et al. 1998; Takeuchi et al. 1996). The types of lesions 
induced by these species depend on the phytotoxins and virulence factors carried by the species and, also, on the timing of infection, potato cultivar and environmental conditions (Bignell et al. 2014; Loria et al. 1997; Natsume et al. 2017). Therefore, it is difficult to distinguish scab pathogens based on disease symptoms.

The common scab symptoms caused by $S$. scabies and S. turgidiscabies are attributable to thaxtomin A (Fig. 1) (Goyer et al. 1998; Lawrence et al. 1990; Toth et al. 1998), a cyclic dipeptidic phytotoxin produced by these bacteria (King et al. 1989; King and Calhoun 2009). The genes required for thaxtomin synthesis, virulence and colonization of tubers are located in two or three genomic regions in S. scabies and S. turgidiscabies and are collectively referred to as a pathogenicity island (PAI) (Aittamaa et al. 2010; Kers et al. 2005). One region of the PAI contains genes for thaxtomin synthesis and is called the toxicogenic region (Lerat et al. 2009). The $t x t D$ gene in the region encodes a nitric oxide (NO) synthase that generates NO from L-arginine (Kers et al. 2004), while the $t x t E$ gene product catalyzes nitration of L-tryptophan by $\mathrm{NO}$ and $\mathrm{O}_{2}$ to produce 4-nitroL-tryptophan (Barry et al. 2012). The $t x t A$ and $t x t B$ genes encode non-ribosomal peptide synthetases that combine 4-nitro-L-tryptophan and phenylalanine to form the cyclic dipeptide skeleton of thaxtomin (Healy et al. 2000). The txtC gene encodes a cytochrome P450-type monooxygenase that is required for postcyclization hydroxylation of cyclic dipeptide (Healy et al. 2002). Expression of these genes is regulated by an AraC/XylS-type regulator, $t x t R$, which is also located in the PAI region (Joshi et al. 2007a). The toxicogenic region of PAI shows wide genetic variability among the strains of S. turgidiscabies (Aittamaa et al. 2010), possibly because the PAI or parts of it may be exchanged among Streptomyces strains and species (Kers et al. 2005).

A variety of superficial deformations are observed in potatoes in various areas of the world. Superficial scab symptoms called netted scab occur in Europe and russet scab occurs in Japan and North America (Loria et al. 1997). Classification and identification of the causal agents of netted and russet scab have gained less attention, probably because these symptoms are less severe than common scab. In Japan, a Streptomyces species that induces tortoiseshell-like cracks in the periderm of the potato was isolated and named "S. cheloniumii" (Oniki et al. 1986; Suzui et al. 1988). "S. cheloniumii" was found to be closely related to $S$. diastatochromogenes by a homology search of $16 \mathrm{~S}$ rDNA sequences (Suzui et al. 2004). This species is distinguished from other phytopathogenic Streptomyces spp. by its reddish aerial mycelia, spiny spores forming a spiral spore chain, and no production of melanin or other diffusible pigments (Oniki et al. 1986; Suzui et al. 2004), but an authoritative description of the species has not been published. The Canadian russet scab agent is discerned from the Japanese strain by gray aerial mycelia and smooth surface-spores forming flexuous spore chains (Faucher et al. 1993). The bacterium shows highest similarity to cluster group 14 of Williams et al. (1983), S. aureofaciens, by numerical classification. Phenotypic studies on Streptomyces sp. isolated in France showed that strains isolated from netted scab tissue were different from the pathogens of common scab or agents isolated from russet scab in Canada (Bouchek-Mechiche et al. 1998). The Streptomyces strains causing netted scab in France were described as a new species, $S$. reticuliscabiei (type strain DSM41804; CFBP 4531) (Bouchek-Mechiche et al. 2000a, b), but were later found to belong to $S$. turgidiscabies (Bouchek-Mechiche et al. 2006). This strain is characterized by the production of light grey spores that make flexuous chains, and the lack of melanin production (BouchekMechiche et al. 2000a). The strain is pathogenic to only few potato cultivars such as Bintje, Desirée and Carmine and does not infect carrot or radish (Bouchek-Mechiche et al. 2000b). Other Streptomyces spp. causing common scab have a wide host range among root crops, including carrot and radish (Wanner and Kirk 2015).

Among the Streptomyces spp. that produce superficial symptoms, "S. cheloniumii" was found to produce phytotoxin FD-891 (Fig. 1), which induces necrosis in potato tuber slices (Natsume et al. 2005). The phytotoxin FD-891 was detected in potatoes infected by the pathogen and was also produced by other pathogenic strains of "S. cheloniumii" collected from different geographical areas in Japan.

In northern Sweden and Finland, S. turgidiscabies is a typical causal agent of common scab (Aittamaa et al. 2010; Kreuze et al. 1999; Lehtonen et al. 2004). Surveys of potato

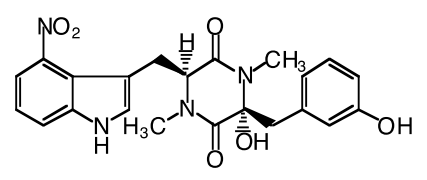

Thaxtomin A

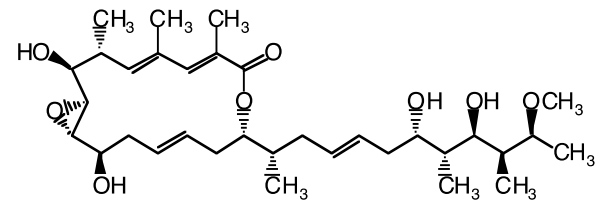

FD-891

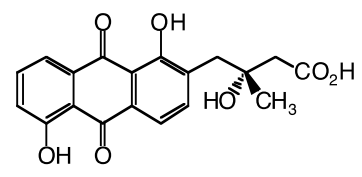

Fridamycin $\mathrm{E}$

Fig. 1 Structure of phytotoxins produced by phytopathogenic Streptomyces spp 
scab pathogens in these regions revealed a few tubers with netted scab symptoms (Bång 1979; Lindholm et al. 1997). Streptomyces sp. strain 65 isolated from a netted scabaffected tuber of potato cv. Bintje in northern Sweden caused netted scab following inoculation of healthy Bintje plants under controlled conditions (Fig. 2).

We hypothesized that the different types of scab lesions on potato are caused by different phytotoxins and have been searching for them in Streptomyces strains (Natsume et al. $1998,2005,2017)$. The aim of this study was to make a molecular level comparison of Streptomyces sp. strain 65 with common scab pathogens previously detected in northern Sweden and Finland and to analyze the phytotoxins produced by strain 65 .

\section{Materials and methods}

\section{Taxonomical identification of streptomyces sp. Strain 65}

Phytopathogenic Streptomyces sp. strain 65 was isolated from a netted scab-affected tuber of potato cv. Bintje in northern Sweden (Lehtonen et al. 2004). Isolation of DNA and amplification by polymerase chain reaction (PCR) with species-specific primers for S. turgiciscabies and S. scabies were carried out as described previously (Kreuze et al. 1999; Lehtonen et al. 2004).

\section{Microarray analysis}

Microarray analysis of Streptomyces sp. strain 65 was carried out with 131 probes designated for the predicted genes of S. scabies to target the genes involved in the thaxtomin biosynthesis and genes previously shown to be related to pathogenicity, including necl, tomA and fas (Aittamaa et al. 2010). We used genomic DNA for the analysis because the aim was to analyze genomic differences rather than differences in gene expression.

\section{Phytotoxicity tests and HPLC analysis of phytotoxins}

Phytotoxicity of microbial extracts and fractions during purification was examined by application to rape (Brassica rapa L.) seedlings and monitoring their growth, as reported previously (Natsume et al. 2005). Possible effects of isolated phytotoxin on potato were studied by applying phytotoxin in methanol at different concentrations (3.6 or $1.2 \mu \mathrm{g} / \mu \mathrm{L}$ ) on microtubers of potato cv. Bintje grown in vitro. The microtubers (10-15 $\mathrm{mm}$ in diameter) were placed on water agar in Petri dishes, and $50 \mu \mathrm{L}$ of phytotoxin solution was applied to each microtuber. The lids of Petri dishes were closed and tubers were grown in a growth chamber at $22{ }^{\circ} \mathrm{C}$ for 3 weeks.

Thaxtomin A production by Streptomyces sp. strain 65 and $S$. turgidiscabies NBRC $16080^{\mathrm{T}}$ was analyzed using HPLC system LC-10 (Shimadzu, Kyoto, Japan) as described previously (Natsume et al. 1998, 2005).

\section{Isolation and identification of the phytotoxin produced by streptomyces sp. Strain 65}

Streptomyces sp. strain 65 was cultured with shaking in potato peel broth (Beauséjour et al. 1999) at $28{ }^{\circ} \mathrm{C}$ for 14 days. The cultured material was filtered to separate the mycelial mass and filtrate. Mycelia were soaked in acetone for 2 days, the residue was filtered out, and the acetone extract was evaporated. The residual aqueous mycelial extract and culture filtrate were treated with chloroform at $\mathrm{pH} 3$ to yield a chloroform-soluble crude extract. Phytotoxin was purified from the extract by column chromatography and preparative TLC as shown in Fig. 3.
Fig. 2 Netted scab symptoms caused by Streptomyces turgidiscabies strain 65 in potato $\mathrm{cv}$. Bintje

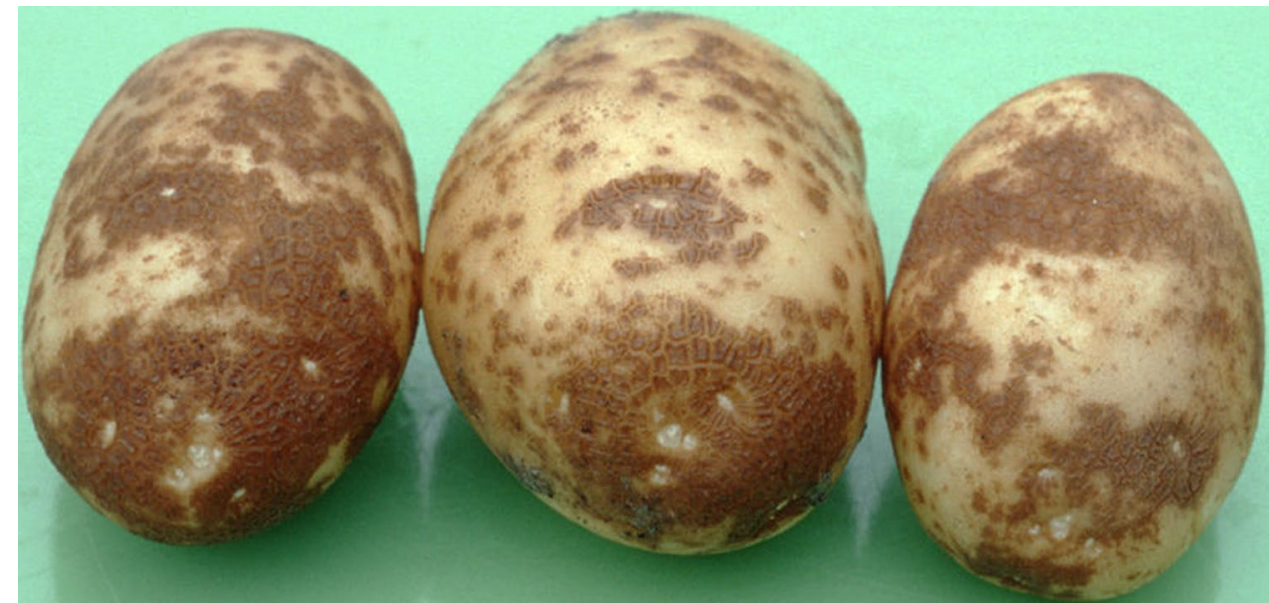


Fig. 3 Purification of the phytotoxin produced by $S$. turgidiscabies strain 65. Isolation steps (a), chromatogram and fractionation in preparative TLC (b) and growth inhibitory activity of fractionated samples (c). Each fraction from the preparative TLC equivalent to $20 \mathrm{~mL}$ of cultured material was used for the growth inhibitory assay a

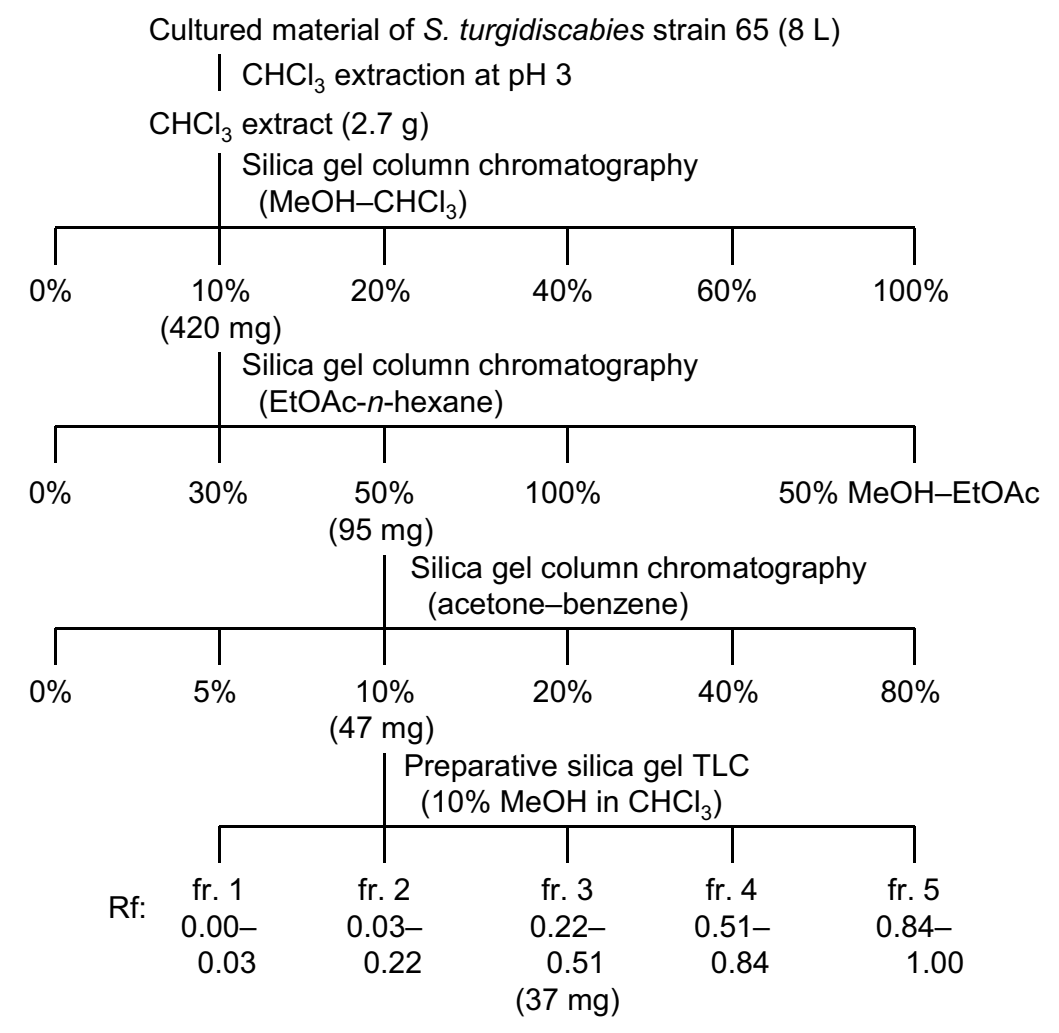

b
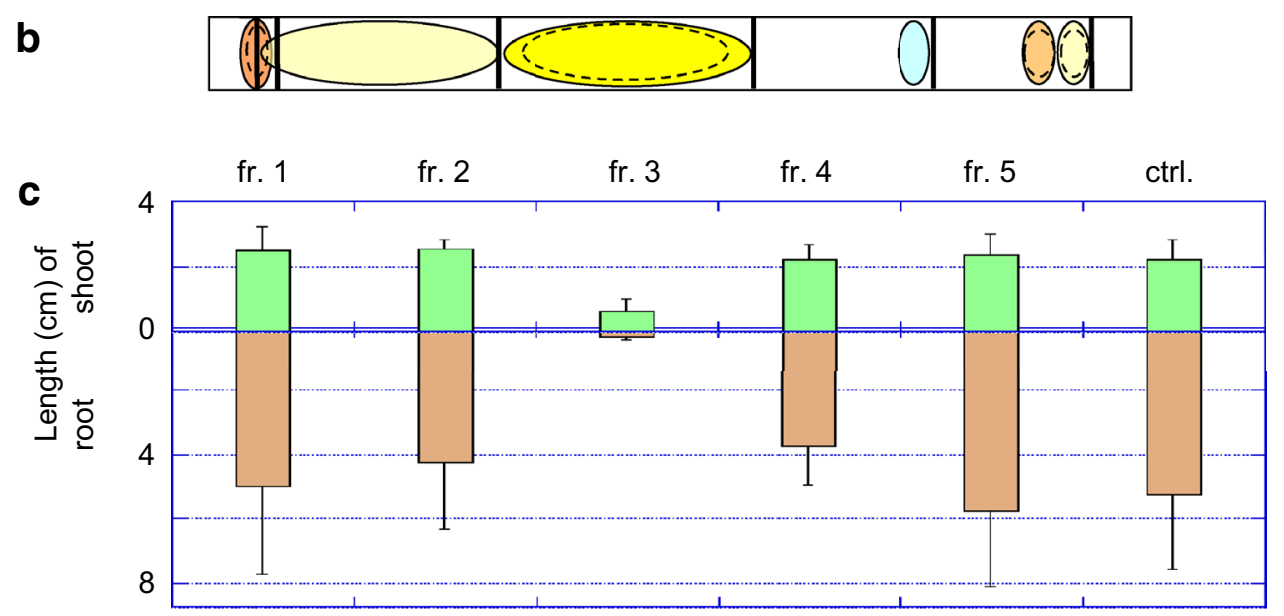

\section{Results}

\section{Identification of strain 65 as S. turgidiscabies}

The 16S rRNA gene from strain 65 was amplified by PCR with specific primers for $S$. turgidiscabies but not with the primers specific to $S$. scabies (Fig. 4). On the other hand, genes necl and tnp located in the "colonization region" of the PAI were not amplified from strain 65 with the primers designed for $S$. turgidiscabies. The 16S rRNA gene sequence of strain 65 was determined (NCBI accession no. AJ278759) and found to be identical or nearly identical to many strains of $S$. turgidiscabies that cause common scab on potato (Aittamaa et al. 2010). Furthermore, the 16S RNA gene sequence of strain 65 was 98-99\% identical to that of $S$. reticuliscabiei strain CFBP4531 and DSM41804 that cause netted scab on potatoes in France. Phylogenetic comparison indicated that strain 65 and $S$. reticuliscabiei are closely related and belong to $S$. turgidiscabies (Fig. 5).

\section{Microarray analysis of thaxtomin biosynthetic genes of S. turgidiscabies strain 65}

Genes involved in thaxtomin biosynthesis and pathogenicity of $S$. turgidiscabies strain 65 were studied using microarray analysis and compared with (1) S. turgidiscabies strains 


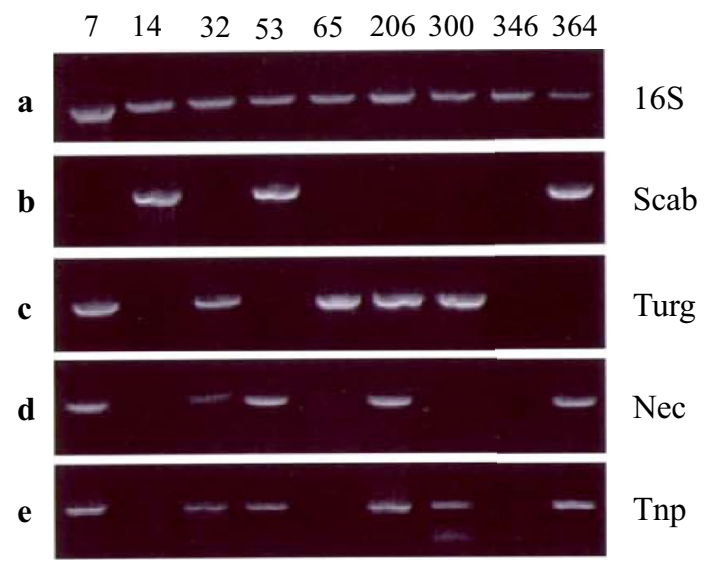

Fig. 4 PCR analysis of selected genes located in the pathogenicity island using a universal Streptomyces primers for the $16 \mathrm{~S}$ gene (16S); b species-specific primers for $S$. scabies (Scab); c specific primers for S. turgidiscabies (Turg); and primers for $\mathbf{d}$ the necl gene (Nec) and e tnp, a transposase pseudogene located upstream and separated by an intergenic region from necl (Tnp). The numbers above the lanes identify the tested Streptomyces strains described previously (Lehtonen et al. 2004)
32 and 300 which produce thaxtomin A but differ in having high and low virulence on potato tubers, respectively (Hiltunen et al. 2005); (2) S. reticuliscabiei DSM 41,804 isolated from a netted scab lesion on potato cv. Bintje in France (Bouchek-Mechiche et al. 2000a), and (3) the type strain of S. scabies (ATCC49173). In S. turgidiscabies strain 32, all probes generated strong signals, e.g., for the genes $t x t A, t x t B, t x t C$, $t x t D$ and $t x t R$ involved in thaxtomin biosynthesis and gene necl involved in virulence (Fig. 6) (Bukhalid et al. 1998; Joshi et al. 2007b). Presence of the aforementioned genes was detected also in S. scabies ATCC49173. In contrast, $S$. turgidiscabies strain 65 and $S$. reticuliscabiei DSM41804 showed no signal for these genes.

\section{Phytotoxin production of S. turgidiscabies strains 65 and NBRC $16080^{\top}$}

The phytotoxicity of crude chloroform extracts of strain 65 and the type strain of $S$. turgidiscabies, NBRC 16080, cultured on oatmeal agar (Babcock et al. 1993) was examined on rape seedlings. Extracts of both strains showed strong growth inhibitory activity at the dose corresponding to the amount of extract obtained from $10 \mathrm{~mL}$ of bacterial culture (Fig. S1).

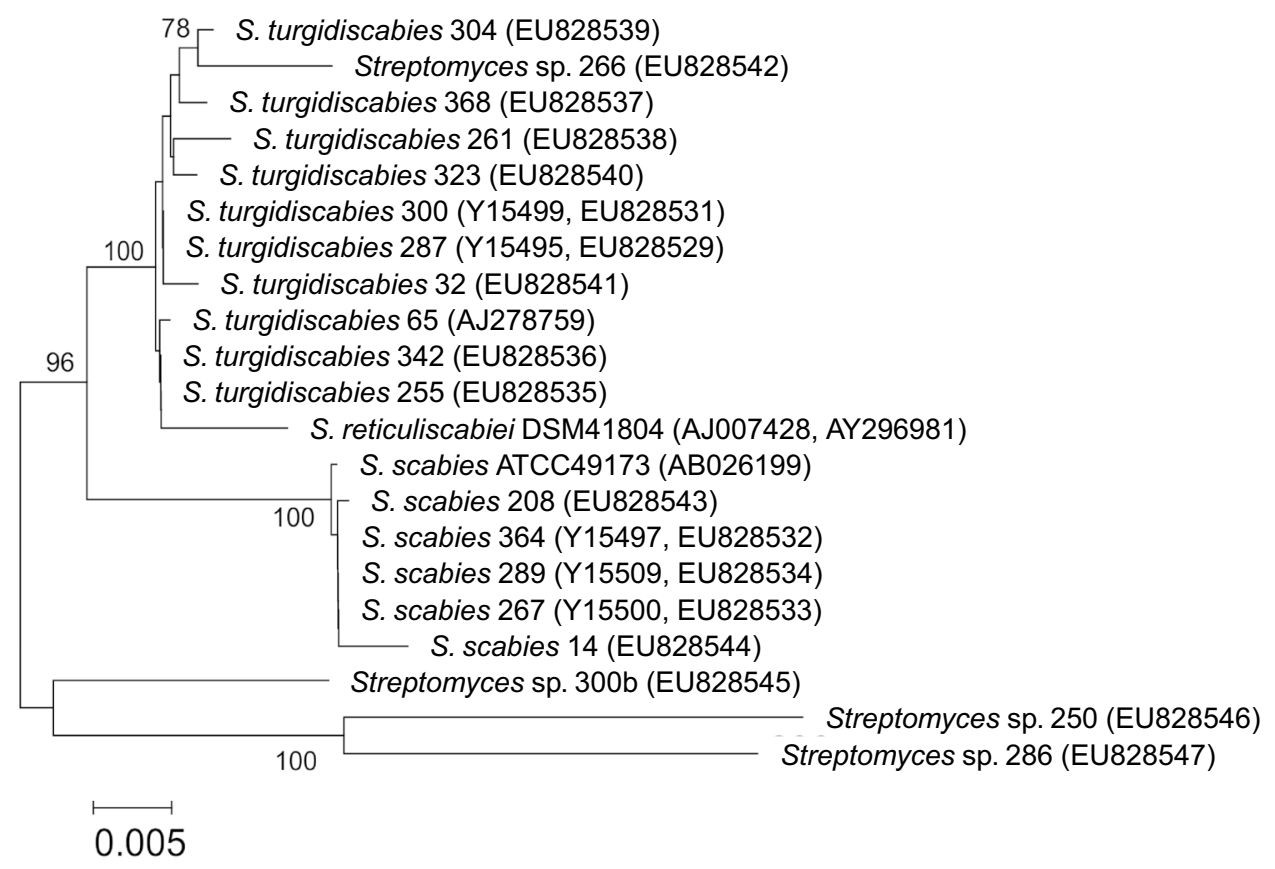

Fig. 5 Clustering of Streptomyces strains by neighbor-joining analysis based on sequences of the 16S RNA cistrons. The tree was constructed using the Kimura two-parameter model (Kimura 1980). Bootstrap values were determined by 1000 replicates; values greater than $70 \%$ are shown. Bar indicates the Kimura nucleotide differences (Knuc). All strains isolated from scabby potato tubers, except strain 65 , have been described previously (Aittamaa et al. 2010). The upper- most cluster contains strains of $S$. turgidiscabies, including DSM1804 originally described as $S$. reticuliscabiei (Bouchek-Mechiche et al. 2000a, 2006). Strain 266 belongs to an unknown species related to $S$. turgidiscabies. The cluster in the middle contains strains of $S$. scabies, including the type strain ATCC49173. Unknown nonpathogenic Streptomyces strains form the clade at the bottom of the tree 
Fig. 6 Microarray analysis: Heat map indicating mean signal densities (red color) given by probes that target different genes in the pathogenicity island (PAI) region of Streptomyces strains. The microarray included 1-5 probes for 30 open reading frames (ORFs) in the three characterized PAI regions of $S$. turgidiscabies strain Car8 (separated by dotted lines) (Kers et al. 2005; Aittamaa et al. 2010). PAI regions I and II contain nine genes typical to the "colonization region" (CR), such as necl contributing to virulence, whereas PAI III includes the genes needed for thaxtomin synthesis and is called a "toxicogenic region” (TR) (Lerat et al. 2009). (Color figure online)

The chloroform extract was purified by silica-gel column chromatography and analyzed by HPLC. Thaxtomin A was detected in the extract of strain NBRC $16080^{\mathrm{T}}$ but not in that of strain 65 (Fig. S2). The result is consistent with previous results in microarray analysis showing that the toxicogenic region genes for thaxtomin production differ between strain 65 with thaxtomin-producing Streptomyces strains.

\section{Isolation of phytotoxin produced by S. turgidiscabies strain 65}

Comparison of phytotoxin production in agar and liquid cultures with oatmeal, oat bran and potato peel media (Babcock et al. 1993; Beauséjour et al. 1999; Goyer et al. 1998) showed that shake culture in potato peel broth provided high phytotoxin productivity and facilitated mass culture (Fig. S3), and this culture method was selected for further experiments.

Phytotoxin was purified as outlined in Fig. 3a, b according to the bioassay. In the first column chromatography on silica gel, $10 \% \mathrm{MeOH}$ in $\mathrm{CHCl}_{3}$ fraction showed phytotoxic activity. Under these conditions, thaxtomin A was recovered in $20 \% \mathrm{MeOH}$ in $\mathrm{CHCl}_{3}$ fraction and, thus, the presence of new phytotoxin was determined. In this purification, $37.1 \mathrm{mg}$ of orange-yellow compound was isolated from $8 \mathrm{~L}$ of culture. Only one fraction showed phytotoxicity at each chromatographic step. This newly isolated phytotoxin had an $R_{\mathrm{f}}$ value of 0.30 that was indistinguishable from thaxtomin A on silica gel TLC (solvent: $10 \% \mathrm{MeOH}$ in $\mathrm{CHCl}_{3}$ ). Both phytotoxins had a very similar yellow color.

\section{Structural determination of the phytotoxin}

HPLC-PDA analysis of the isolated phytotoxin showed a single peak (Fig. S4), and the UV spectrum of the peak showed $\lambda_{\max }$ at 433, 289, 254 and $215 \mathrm{~nm}$ (Fig. S5). This UV spectrum is characteristic of the presence of a 1,5-dihydroxyanthraquinone chromophore such as $\alpha$-citromycinone (Johdo et al. 1991). LC-ESI-MS analysis of the isolated phytotoxin shows peaks at $m / z$ 735, 730, 379, 357 and 339, which can be assigned to ions $[2 \mathrm{M}+\mathrm{Na}]^{+},\left[2 \mathrm{M}+\mathrm{H}_{2} \mathrm{O}\right]^{+}$, $[\mathrm{M}+\mathrm{Na}]^{+},[\mathrm{M}+\mathrm{H}]^{+}$and $\left[\mathrm{M}+\mathrm{H}-\mathrm{H}_{2} \mathrm{O}\right]^{+}$. From these data, the molecular weight of the phytotoxin was determined
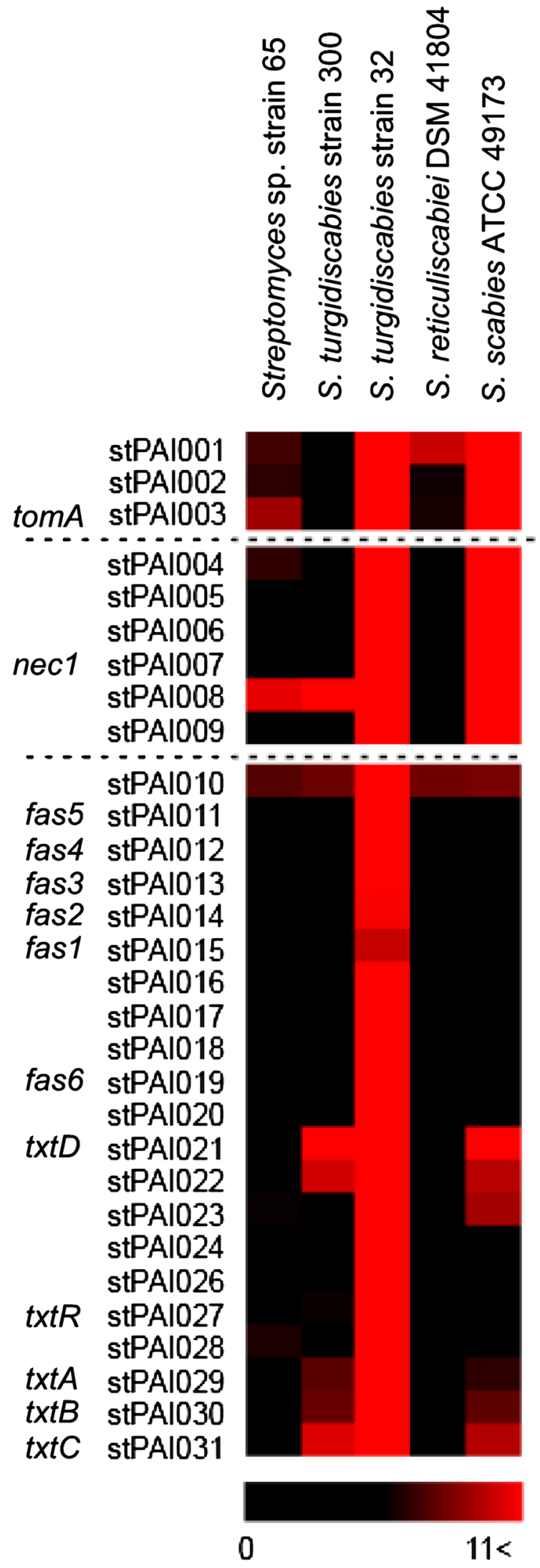
to be 356 . The molecular formula $\mathrm{C}_{19} \mathrm{H}_{16} \mathrm{O}_{7}$ was deduced from high-resolution MS data, $\mathrm{m} / z 357.09855$ (calculated for $\mathrm{C}_{19} \mathrm{H}_{17} \mathrm{O}_{7}$ : 357.09743).

The presence of one carboxyl group was demonstrated by disappearance of the peak in the mass chromatogram at $\mathrm{m} / \mathrm{z}$ 357 and appearance of a peak at $m / z 371$ by LC-ESI-MS analysis of phytotoxin treated with trimethylsilyldiazomethane in methanol-benzene (Hashimoto et al. 1981).

The ${ }^{1} \mathrm{H}-\mathrm{NMR}$ spectrum $\left(600 \mathrm{MHz}, \mathrm{CD}_{3} \mathrm{OD}\right.$, Fig. S6) revealed three adjacent aromatic protons $(\delta 7.72[\mathrm{~d}$, $J=8.1 \mathrm{~Hz}), 7.62[\mathrm{dd}, J=8.1,8.1 \mathrm{~Hz}]$ and $7.21[\mathrm{~d}, J=8.1$ $\mathrm{Hz}]) ; 2$ aromatic protons with ortho-coupling $(\delta 7.66[\mathrm{~d}$, $J=8.1 \mathrm{~Hz}]$ and $7.65[\mathrm{~d}, J=8.1 \mathrm{~Hz}]) ; 2$ pairs of isolated methylene protons $(\delta 2.93[\mathrm{~d}, J=13.2 \mathrm{~Hz})] 2.90[\mathrm{~d}, J=13.2$ $\mathrm{Hz}]$ and $\delta 2.28$ [d, $J=15.4 \mathrm{~Hz}], 2.22[\mathrm{~d}, J=15.4 \mathrm{~Hz}])$; and a quarternary methyl signal $(\delta 1.13,3 \mathrm{H}, \mathrm{s})$.

Searches in the SciFinder database based on the aforementioned structural characteristics identified fridamycin $\mathrm{E}$ as the structural candidate. Comparison of isolated phytotoxin with the authentic fridamycin E in the HPLC-UV-Vis database system (Fiedler 1993) showed an identical HPLC chromatogram, UV spectrum and ESI-MS spectra (positive and negative ion modes) (Fig. S7). We thus identified the phytotoxin produced by $S$. turgidiscabies strain 65 as fridamycin E (Fig. 1). The absolute stereochemistry of isolated fridamycin $\mathrm{E}$ was the same as previously reported (Matsumoto et al. 1991) by the positive optical rotation of the isolated sample $\left([\alpha]_{\mathrm{D}}{ }^{28}+4.3^{\circ}[c=0.49\right.$, dioxane $\left.]\right)$.

\section{Phytotoxicity of fridamycin E}

The purified phytotoxin caused a $17 \%$ reduction in root growth and a $14 \%$ reduction in shoot growth at $14 \mu \mathrm{g} / \mathrm{mL}$ in rape seedlings and a $96 \%$ reduction in root growth and a $75 \%$ reduction in shoot growth at $100 \mu \mathrm{g} / \mathrm{mL}$ (Fig. 3c). Thaxtomin A caused a 24\% reduction in root growth and a $25 \%$ reduction in shoot growth in rape seedlings at $0.16 \mu \mathrm{g} /$ $\mathrm{mL}$, which indicates that the phytotoxicity of fridamycin $\mathrm{E}$ is approximately $1 \%$ of that of thaxtomin A.

Application of fridamycin $\mathrm{E}$ to potato microtubers at a concentration of $3.6 \mu \mathrm{g} / \mu \mathrm{L}$ reduced the growth of sprouts or inhibited sprouting of potato microtubers grown in vitro. Typical netted scab symptoms were not observed on the microtubers, but a few small scab-like lesions were observed under the present experimental conditions (Fig. 7). Application of fridamycin $\mathrm{E}$ at a lower concentration $(1.2 \mu \mathrm{g} / \mu \mathrm{L})$ caused only minor or no reduction in growth of sprouts and no symptoms on the microtubers (data not shown).

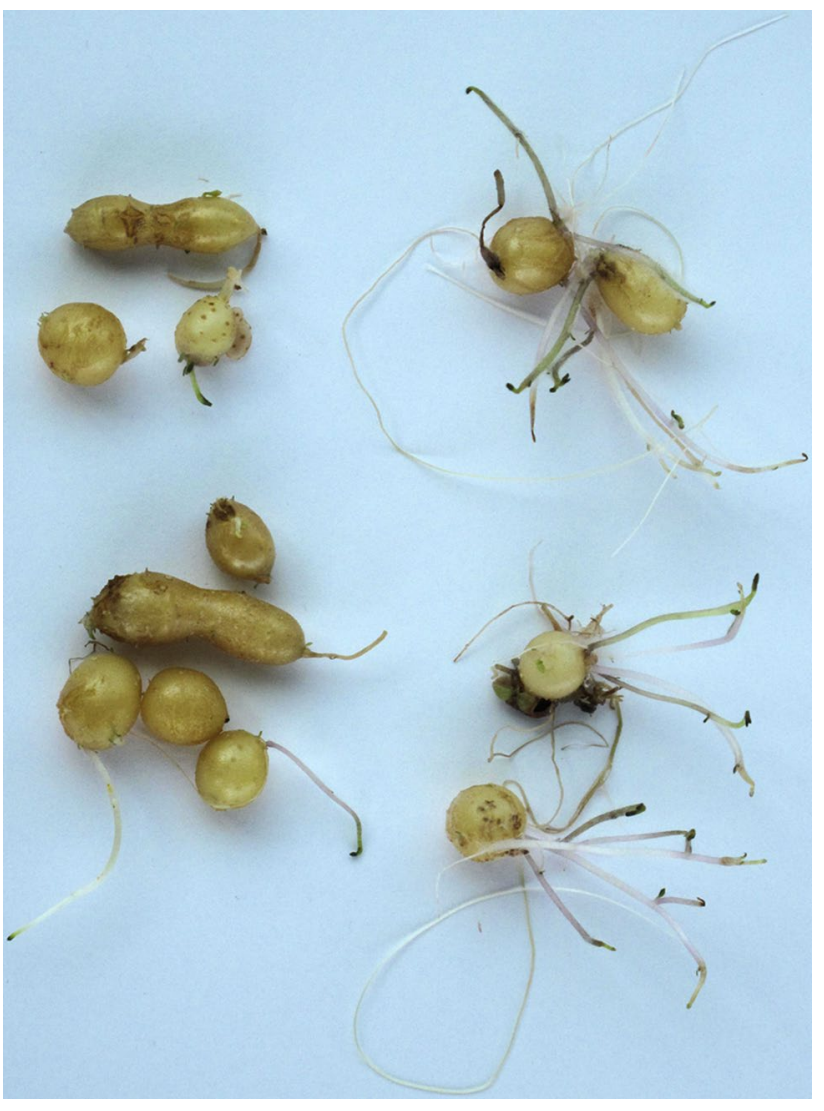

Fig. 7 Inhibited sprouting and sprout elongation on microtubers of potato $\mathrm{cv}$. Bintje following application of fridamycin $\mathrm{E}$ in methanol at $3.6 \mu \mathrm{g} / \mu \mathrm{L}$ (50 $\mu \mathrm{L} /$ tuber) (to the left) compared with microtubers treated with methanol only (right)

\section{Effect of plant extracts on phytotoxin production}

Requirements of plant extracts such as oatmeal for thaxtomin production by S. scabies have been reported (Beauséjour et al. 1999), and effective ingredients were shown to be suberin and cellobiose (Beauséjour et al. 1999; Johnson et al. 2007; Lerat et al. 2010). We examined the requirements for phytotoxin production in S. turgidiscabies strain 65 and NBRC $16080^{\mathrm{T}}$ by culturing on oatmeal agar and starch-polypeptone agar (Sakai et al. 1984). Crude chloroform extracts of strain NBRC16080 prepared from oatmeal agar strongly inhibited growth of rape seedlings but those from starch-polypeptone medium did not (Fig. 8). Thaxtomin A content in oatmeal agar culture was determined to be $0.39 \mu \mathrm{g} / \mathrm{mL}$ of cultured material by HPLC analysis of the partially purified extracts. Both extracts of strain 65 showed comparable growth inhibitory activity (Fig. 8), and fridamycin E production was determined to be $0.83 \mu \mathrm{g} / \mathrm{mL}$ in both media. Thus, fridamycin E production by strain 65 does not require any plant extract. 
Fig. 8 Effect of plant extract on production of phytotoxin. Ctrl control, $O A$ oatmeal agar, SPA starch-polypeptone agar. Growth inhibitory activity of the crude $\mathrm{CHCl}_{3}$ extract was examined at the dose equivalent to $10 \mathrm{~mL}$ of cultured material
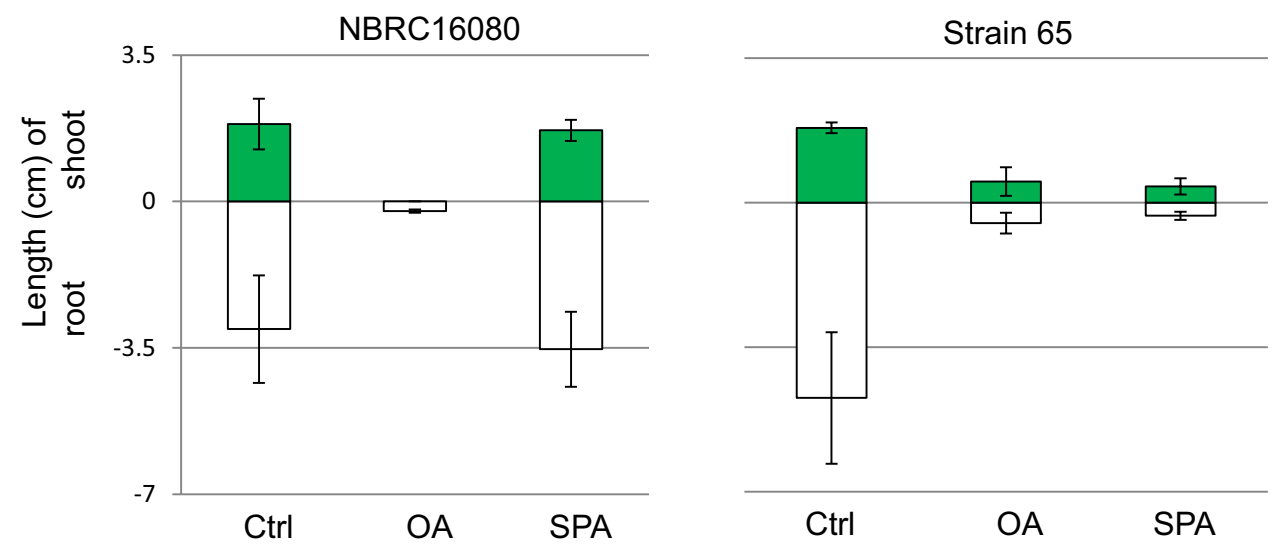

\section{Discussion}

Streptomyces on potato tubers cause a severe symptom with raised, erumpent, or pitted lesions and milder symptoms characterized by superficial lesions (Loria et al. 1997). Various symptoms caused by Streptomyces spp. are considered to be related to the level of virulence of the pathogen, the amount of phytotoxin (thaxtomin) produced, infection timing in relation to developmental stage of tubers, genetic differences among potato varieties and environmental conditions. The finding that potato cv. Green Mountain is very susceptible to common scab but highly resistant to netted scab (Loria et al. 1997) suggests that the pathogenicity determinants of Streptomyces strains causing netted scab differ from those causing common scab.

Extensive investigations of potato diseases caused by Streptomyces in northern Sweden revealed a strain causing only superficial lesions on tubers of potato cv. Bintje (Lehtonen et al. 2004). Genetic analysis of the bacterium in this study showed that the strain belongs to species $S$. turgidiscabies but that its toxicogenic region in PAI, including the thaxtomin biosynthetis gene cluster, differs from that of S. turgidiscabies which causes deep pitting and other severe scab symptoms. Consistent with these findings, S. turgidiscabies strain 65 did not produce thaxtomin but did produce a newly identified phytotoxin called fridamycin E. Fridamycin $\mathrm{E}$ is the aglycone of fridamycin $\mathrm{A}$ (= vineomycinone $B_{2}$ ) (Matsumoto et al. 1991), but there is no report on its biosynthetic pathway or biosynthetic genes.

Application of fridamycin $\mathrm{E}$ to potato microtubers inhibited sprouting or reduced the growth of sprouts in a concentration-dependent manner. Antibiotic activity of fridamycin E against Gram-positive bacteria has been reported (Matsumoto et al. 1991), but this is the first report of phytotoxicity associated with fridamycin $\mathrm{E}$.

Application of fridamycin E to potato microtubers did not cause any obvious netted scab symptom. One reason may be that we applied the phytotoxin once rather than repeatedly over time. For the formation of netted scab symptoms, continuous production of phytotoxin on the epidermis by the pathogen may be required. Further experimentation will be needed to confirm whether fridamycin $\mathrm{E}$ is essential for development of netted scab and whether repeated applications of fridamycin $\mathrm{E}$ are required.

We previously found that bacteria isolated from russet scab lesions in Japan produces another phytotoxin FD-891 (Natsume et al. 2005). It has been suggested that the pathogenicity determinants of netted scab differ from those of common scab because resistance of potato cultivars to the netted scab pathogens is not correlated with resistance to the common scab pathogen, S. scabies (Loria et al. 1997). Identification of a novel phytotoxic macrolide, FD-891, in "S. cheloniumii" (Natsume et al. 2005) and an anthraquinone phytotoxin, fridamycin E, in S. turgidiscabies strain 65 supports the hypothesis. The results of the present study, along with our previous findings on FD-891, are important for demonstrating that the toxins produced by the pathogen determine the lesion type. Recently, we have shown that phytotoxin concanamycin is involved in determination of lesion type of common scab along with thaxtomin (Natsume et al. 2017).

S. reticuliscabiei was, at first, reported as the agent of netted scab in France (Bouchek-Mechiche et al. 2000a, b) but was later identified as strain S. turgidiscabies by DNA-DNA hybridization and phylogenetic comparisons of 16S rRNA gene sequences (Bouchek-Mechiche et al. 2006). However, because the symptoms caused by $S$. reticuliscabiei are distinct from the symptoms typically caused by $S$. turgidiscabies, Bouchek-Mechiche et al. (2006) proposed maintaining the species name. Strain 65 of S. turgidiscabies causes symptoms similar to $S$. reticuliscabiei in potato cv. Bintje, but both $S$. reticuliscabiei and strain 65 are also pathogenic on other potato varieties (Kreuze et al. 1999; BouchekMechiche et al. 2000b; Lehtonen et al. 2004). Hence, it is worthwhile to consider whether both $S$. reticuliscabiei and strain 65 could be considered as strains of $S$. turgidiscabies. Whether S. reticuliscabiei produces fridamycin $\mathrm{E}$ is an interesting topic for further study. 
To prove that fridamycin $\mathrm{E}$ is the causal agent of netted scab in northern Europe, we are now studying (1) pathogenicity of the fridamycin E-nonproducing mutants and (2) detection of fridamycin $\mathrm{E}$ in the lesions of netted scab caused by S. turgidiscabies strain 65 .

Acknowledgements This collaborative research began on the occasion of International Potato Scab Symposium held in Sapporo in 2004. The authors express their deep appreciation to Prof. Emeritus Shigeo Naito of Hokkaido University, chair of the organizing committee.

Open Access This article is distributed under the terms of the Creative Commons Attribution 4.0 International License (http://creativecommons.org/licenses/by/4.0/), which permits unrestricted use, distribution, and reproduction in any medium, provided you give appropriate credit to the original author(s) and the source, provide a link to the Creative Commons license, and indicate if changes were made.

\section{References}

Aittamaa M, Somervuo P, Laakso I, Auvinen P, Valkonen JPT (2010) Microarray-based comparison of genetic differences between strains of Streptomyces turgidiscabies with focus on the pathogenicity island. Mol Plant Pathol 11:733-746

Babcock MJ, Eckwall EC, Schottel JL (1993) Production and regulation of potato-scab-inducing phytotoxins by Streptomyces scabies. J Gen Microbiol 139:1579-1586

Bång H (1979) Studies on potato russet scab. I. A characterization of different isolates from northern Sweden. Acta Agric Scand 29:145-150

Barry SM, Kers JA, Johnson EG, Song L, Aston PR, Patel B, Krasnoff SB, Crane BR, Gibson DM, Loria R, Challis GL (2012) Cytochrome P450-catalyzed 1-tryptophan nitration in thaxtomin phytotoxin biosynthesis. Nat Chem Biol 8:814-816

Beauséjour J, Goyer C, Vachon J, Beaulieu C (1999) Production of thaxtomin A by Streptomyces scabies strains in plant extract containing medium. Can J Microbiol 45:764-768

Bignell DRD, Fyans JK, Cheng Z (2014) Phytotoxins produced by plant pathogenic Streptomyces species. Appl Microbiol 116:223-235

Bouchek-Mechiche K, Guérin C, Jouan B, Gardan L (1998) Streptomyces species isolated from potato scabs in France: numerical analysis of "Biotype-100" carbon source assimilation data. Res Microbiol 149:653-663

Bouchek-Mechiche K, Gardan L, Normand P, Jouan B (2000a) DNA relatedness among strains of Streptomyces pathogenic to potato in France: description of three new species, S. europaeiscabiei sp. nov. and S. stelliscabiei sp. nov. associated with common scab, and $S$. reticuliscabiei sp. nov. associated with netted scab. Int J Syst Evol Microbiol 50:91-99

Bouchek-Mechiche K, Pasco C, Andrivon D, Jouan B (2000b) Differences in host range, pathogenicity to potato cultivars and response to soil temperature among Streptomyces species causing common and netted scab in France. Plant Pathol 49:3-10

Bouchek-Mechiche K, Gardan L, Andrivon D, Normand P (2006) Streptomyces turgidiscabies and Streptomyces reticuliscabiei: one genomic species, two pathogenic groups. Int J Syst Evol Microbiol 56:2771-2776

Bukhalid RA, Chung SY, Loria R (1998) necl, a gene conferring a necrogenic phenotype, is conserved in plant-pathogenic Streptomyces spp. and linked to a transposase pseudogene. Mol PlantMicrobe Interact 11:960-967
DSMZ (2017) Catalogue of microorganisms. https://www.dsmz.de/ catalogues/catalogue-microorganisms.html. Accessed 24 Jun 2017

Faucher E, Otrysko B, Paradis É, Hodge NC, Stall RE, Beaulieu C (1993) Characterization of streptomycetes causing russet scab in Québec. Plant Dis 77:1217-1220

Fiedler H-P (1993) Biosynthetic capacities of actinomycetes. 1. Screening for secondary metabolites by HPLC and UV-visible absorbance spectral libraries. Nat Prod Lett 2:119-128

Goyer C, Vachon J, Beaulieu C (1998) Pathogenicity of Streptomyces scabies mutants altered in thaxtomin A production. Phytopathology 88:442-445

Hashimoto N, Aoyama T, Shioiri T (1981) New methods and reagents in organic synthesis. 14. A simple efficient preparation of methyl esters with trimethylsilyldiazomethane $\left(\mathrm{TMSCHN}_{2}\right)$ and its application to gas chromatographic analysis of fatty acids. Chem Pharm Bull 29:1475-1478

Healy FG, Wach M, Krasnoff SB, Gibson DM, Loria R (2000) The txtAB genes of the plant pathogen Streptomyces acidiscabies encode a peptide synthease required for phytotoxin thaxtomin A production and pathogenicity. Mol Microbiol 38:794-804

Healy FG, Krasnoff SB, Wach M, Gibson DM, Loria r (2002) Involvement of a cytochrome $\mathrm{P} 450$ monooxygenase in thaxtomin A biosynthesis by Streptomyces acidiscabies. J Bacteriol 184:2019-2029

Hiltunen LH, Weckman A, Ylhäinen A, Rita H, Richter E, Valkonen JPT (2005) Responses of potato cultivars to the common scab pathogens, Streptomyces scabies and S. turgidiscabies. Ann Appl Biol 146:395-403

Johdo O, Ishikura T, Yoshimoto A, Takeuchi T (1991) Anthracycline metabolites from Streptomyces violaceus A262 I. Isolation of antibiotic-blocked mutants from Streptomyces violaceus A262. J Antibiot 44:1110-1120

Johnson EG, Joshi MV, Gibson DM, Loria R (2007) Cellooligosaccharides released from host plants induce pathogenicity in scab-causing Streptomyces species. Physiol Mol Plant Pathol $71: 18-25$

Joshi MV, Bingell DRD, Johnson EG, Sparks JP, Gibson DM, Loria $\mathrm{R}$ (2007a) The AraC/XylS regulator TxtR modulates thaxtomin biosynthesis and virulence in Streptomyces scabies. Mol Microbiol 66:633-642

Joshi M, Rong X, Moll S, Kers J, Franco C, Loria R (2007b) Streptomyces turgidiscabies secretes a novel virulence protein, Nec1, which facilitates infection. Mol Plant-Microbe Interact 20:599-608

Kers JA, Wach MJ, Krasnoff SB, Widom J, Cameron KD, Bukhalid RA, Gibson DM, Crane BR, Loria R (2004) Nitration of a peptide phytotoxin by bacterial nitric oxide synthase. Nature 429:79-82

Kers JA, Cameron KD, Joshi MV, Bukhalid RA, Morello JE, Waach MJ, Gibson DM, Loria R (2005) A large, mobile pathogenicity island confers plant pathogenicity on Streptomyces species. Mol Microbiol 55:1025-1033

Kimura M (1980) A simple method for estimating evolutionary rates of base substitutions through comparative studies of nucleotide sequences. J Mol Evol 16:111-120

King RR, Calhoun LA (2009) The thaxtomin phytotoxins: sources, synthesis, biosynthesis, biotransformation and biological activity. Phytochemistry 70:833-841

King RR, Lawrence CH, Clark MC, Calhoun LA (1989) Isolation and characterization of pytotoxins associated with Streptomyces scabies. J Chem Soc Chem Commun 1989:849-850

Kreuze JF, Suomalainen S, Paulin L, Valkonen JPT (1999) Phylogenetic analysis of 16S rRNA genes and PCR analysis of the necl gene from Streptomyces spp. causing common scab, pitted scab, and netted scab in Finland. Phytopathology 89:462-469

Lambert DH, Loria R (1989) Streptomyces scabies sp. nov., nom. rev. Int J Syst Bacteriol 39:387-392 
Lawrence CH, Clark MC, King RR (1990) Induction of common scab symptoms in aseptically cultured potato tubers by the vivotoxin, thaxtomin. Phytopathology 80:606-608

Lehtonen MJ, Rantala H, Kreuze JF, Bång H, Kuisma L, Koski P, Virtanen E, Vihlman K, Valkonen JPT (2004) Occurrence and survival of potato scab pathogens (Streptomyces species) on tuber lesions: quick diagnosis based on a PCR-based assay. Plant Pathol 53:280-287

Lerat S, Simao-Beaunoir A, Beaulieu C (2009) Genetic and physiological determinants of Streptomyces scabies pathogenicity. Mol Plant Pathol 10:579-585

Lerat S, Simao-Beaunoir A-M, Wu R, Beaudoin N, Beaulieu C (2010) Involvement of the plant polymer suberin and the disaccharide cellobiose in triggering thaxtomin A biosynthesis, a phytotoxin produced by the pathogenic agent Streptomyces scabies. Phytopathology 100:91-96

Lindholm P, Kortemaa H, Kokkola M, Haahtela K, Salkinoja-Salonen M, Valkonen JPT (1997) Streptomyces spp. isolated from potato scab lesions under Nordic conditions. Plant Dis 81:1317-1322

Loria R (2001) Common scab. In: Stevenson WR, Loria R, Franc GD, Weingartner DP (eds) Compendium of potato diseases, 2nd edn. APS Press, St Paul, pp 14-15

Loria R, Bukhalid RA, Fry BA, King RR (1997) Plant pathogenicity in the genus Streptomyces. Plant Dis 81:836-845

Matsumoto T, Jona H, Katsuki M, Suzuki K (1991) Efficient method for introducing vineomycin-fridamycin-type side chain. Total synthesis of fridamycin E. Tetrahedron Lett 32:5103-5106

Miyajima K, Tanaka F, Takeuchi T, Kuninaga S (1998) Streptomyces turgidiscabies sp. nov. Int J Syst Bacteriol 48:492-502

Natsume M, Yamada A, Tashiro N, Abe H (1998) Differential production of the phytotoxins thaxtomin A and concanamycins A and B by potato common scab-causing Streptomyces spp. Ann Phytopathol Soc Jpn 64:202-204
Natsume M, Komiya M, Koyanagi F, Tashiro N, Kawaide H, Abe H (2005) Phytotoxin produced by Streptomyces sp. causing potato russet scab in Japan. J Gen Plant Pathol 71:364-369

Natsume M, Tashiro N, Doi A, Nishi Y, Kawaide H (2017) Effects of concanamycins produced by Streptomyces scabies on lesion type of common scab of potato. J Gen Plant Pathol 83:78-82

Oniki M, Suzui T, Araki T, Sonoda R, Chiba T, Takeda T (1986) Causal agent of russet scab of potato (Japanese with English abstract). Bull Natl Inst Agroenviron Sci 2:45-59

Sakai R, Kawamura H, Mino Y, Emami-Saravi R, Tanii A (1984) Toxin production by Streptomyces spp. associated with scab of potato tuber and sugar beet I. Effect of carbon and nitrogen sources. Ann Phytopathol Soc Jpn 50:646-468

Suzui T, Miyashita K, Tashiro N (1988) Streptomyces cheloniumii sp. nov., a new species causing russet scab of potato. Abstracts of Papers, 5th International Congress of Plant Pathology, Kyoto, p 177

Suzui T, Tashiro N, Mijashita K, Manabe K, Matsuyama N (2004) Studies on the causal organism, ecology and control of potato russet scab in Japan. Proc Int Potato Scab Sym, Sapporo, pp 339-343

Takeuchi T, Sawada H, Tanaka F, Matsuda I (1996) Phylogenetic analysis of Streptomyces spp. causing potato scab based on 16S rRNA sequences. Int. J Syst Bacteriol 46:476-479

Toth L, Akino S, Kobayashi K, Doi A, Tanaka F, Ogoshi A (1998) Production of thaxtomin A by Streptomyces turgidiscabies. Soil Microrg 51:29-34

Wanner LA, Kirk WW (2015) Streptomyces-from basic microbiology to role as a plant pathogen. Am J Potato Res 92:236-242

Williams ST, Goodfellow M, Alderson G, Wellington EMH, Sneath PHA, Sackin MJ (1983) Numerical classification of Streptomyces and related genera. J Gen Microbiol 129:1743-1813 